\author{
Nadine Bednarz \\ Ośrodek Doradztwa Metodycznego \\ i Doskonalenia Nauczycieli w Legnicy
}

\title{
Czy uczenie się przez cale życie jest postawą przedsiębiorczą
}

\section{Kapitał ludzki a edukacja}

Kapitał ludzki definiuje się jako zasób wiedzy, umiejętności, zdrowia i energii witalnej zawarty w danym społeczeństwie. Ponieważ jednak kapitał ludzki jest cechąjakościową danej osoby, nie może on być przedmiotem obrotu rynkowego i zmieniać właściciela. Można go jednak powiększać drogą inwestycji, zwanych inwestycjami w człowieka. W szerokim ujęciu, do inwestycji tworzących zasób kapitału ludzkiego zalicza się wszystkie te inwestycje, które mogą wpływać na poprawę jakościowych cech pracy ludzkiej, czyli inwestycje w zdrowie, ochronę środowiska i kulturę.

Cechą charakterystyczną kapitału ludzkiego jest to, że pozostaje on w stałym związku z dokonującymi się na świecie przemianami w nauce i technice. W literaturze można spotkać wąską i szeroką interpretację tego terminu. W ujęciu wąskim kapitał ludzki jest ujmowany, po pierwsze, jako efekt inwestycji w oświatę i kształcenie, ucieleśniony w cechach jakościowych dostępnego w gospodarce zasobu pracy. Cechy kapitału ludzkiego kształtowane są przez nakłady na szeroko rozumiane badania i prace rozwojowe, gdyż większość z nich wiąże się z procesami typu ,uczenie przez działanie" i ,uczenie przez naukę" ". W ujęciu szerokim do nakładów czy też inwestycji tworzących zasób kapitału ludzkiego zalicza się również inwestycje w zdrowie, ochronę środowiska, kulturę, gdyż podobnie jak oświata oddziałują one na poprawę cech jakościowych pracy ludzkiej.

Przede wszystkim jednak kapitał ludzki interpretowany jest jako efekt inwestycji w oświate i kształcenie. Podkreśla się, że kapitał ludzki:

- wywiera ważny wpływ na konkurencyjność gospodarek, ich zdolności absorpcyjne w dziedzinie przyswajania i wdrażania światowych osiagnięć naukowych, technicznych, organizacyjnych, kulturowych itp.;

- sprzyja kształtowaniu nowoczesnej infrastruktury techniczno-organizacyjnej, informacyjnej itp.;

- korzystnie oddziałuje na przemiany instytucjonalne;

- sprzyja propagowaniu i rozpowszechnianiu się nowoczesnych wzorców konsumpcji, jakości życia i wzorów etyczno-moralnych.

Edukacja rozumiana jest jako wychowanie, wykształcenie, nauka ${ }^{2}$ oraz proces zdobywania wiedzy. Ma ogromną wartość dla człowieka zarówno w wymiarze kapitału, który wnosi on na rynek pracy, jak i w dalszym jego osobistym rozwoju, niezwiązanym z ekonomicznymi perspektywami. Pojedynczy człowiek, jako jednostka uzyskująca wykształcenie, nie bierze pod uwagę tzw. efektów zewnętrznych wykształcenia, wyrażających się m.in. tym, że wzrost wykształcenia

\footnotetext{
${ }^{1}$ B. Fiodor, 2001, Polityka państwa a powiększanie zasobów kapitału ludzkiego w Polsce w latach dziewięćdziesiatych [w:] J. Jagas (red.), Produktywność i wydajność w okresie transformacji gospodarki polskiej, Wydawnictwo Uniwersytetu Opolskiego, Opole.

${ }^{2}$ Stownik języka polskiego, Wydawnictwo Naukowe PWN, Warszawa 1998.
} 
zwiększa nie tylko wydajność jego samego, lecz także wydajność, współpracowników. Efekty zewnętrzne sprawiają, że w teorii ekonomii edukacja jest zaliczana do grupy dóbr społecznie pożądanych. Oznacza to, że państwo powinno zachęcać obywateli do kształcenia się, czyniąc je dostępnym dla wszystkich ${ }^{3}$. Edukacja jest więc ważną inwestycją warunkującą rozwój gospodarki każdego państwa; jest czynnikiem stymulującym wzrost gospodarczy, badania i innowacje, konkurencyjność oraz aktywne postawy obywatelskie.

Kształcenie w warunkach konkurencyjności spełnia wiele funkcji:

1. Funkcja dochodowa - wykształcenie staje się warunkiem osiagnięcia sukcesów ekonomicznych. Następuje dywersyfikacja dochodowa społeczeństwa, zmieniają się proporcje dochodów w różnych zawodach. Praca specjalistów najwyższej klasy jest szczególnie premiowana.

2. Funkcja zatrudnieniowa - istnieje ścisły związek między poziomem wykształcenia a możliwością uzyskiwania dodatkowych kwalifikacji w zawodach, na które jest zapotrzebowanie. Osobom o najwyższych kwalifikacjach najłatwiej przystosować się do wymogów rynku pracy.

3. Funkcja efektywnościowa - osoby o najwyższych kwalifikacjach cechują się wyższą wydajnością pracy.

4. Funkcja kreacyjna - szeroko rozumiana innowacyjność i dynamizm ekonomiczny są efektami aktywności zawodowej specjalistów. Konkurencyjność w skali międzynarodowej wynika w największym stopniu z kreatywności i poziomu innowacyjności społeczeństwa.

5. Funkcja społeczno-wychowawcza - obejmuje proces kształtowania pożądanych społecznie wzorców i zachowań, wdrażanie do dorosłego życia, nauczanie zasad komunikacji społecznej.

6. Funkcja kulturowa - polegająca na kształtowaniu świadomości narodowej, historycznej i społecznej, propagowaniu wzorców kultury, upowszechnianiu języków obcych i poprawnej polszczyzny. ${ }^{4}$

Proces wzrostu społeczno-gospodarczego jest ściśle związany z rozwojem jakościowym kapitału ludzkiego, a ten wymaga podjęcia działań dotyczących formalnych możliwości kształcenia na wszystkich szczeblach, łącznie ze szkoleniem w czasie pracy. Jakość kapitału ludzkiego i jego kreowanie to wynik działań zbiorowych o charakterze instytucjonalnym oraz motywacji indywidualnych. Dlatego też ważną rolę odgrywa:

- kształcenie oferowane przez formalny system edukacji narodowej;

- kształcenie i doskonalenie zawodowe w trakcie zatrudnienia;

- kształcenie ustawiczne.

W dużym uproszczeniu cele ekonomiczne edukacji można sprowadzić do przygotowania kadr kwalifikowanych o poziomie wykształcenia i strukturze zawodowej, które powinny odpowiadać zmiennym w czasie potrzebom gospodarki.

Zadania w dziedzinie edukacji są w dużej mierze zdeterminowane przez sytuację demograficzną, stan infrastruktury w dziedzinie oświaty i kształcenia, liczebność i poziom kwalifikacji nauczycieli oraz ustawodawstwo dotyczące obowiązku szkolnego. Do niedawna Polska była jednym z krajów o najwyższym współczynniku przyrostu naturalnego. W ostatnim dziesięcioleciu współczynnik ten malał i w 2001 r. wyniósł 0,5 na 1000 mieszkańców. Z badań tendencji demograficznych wynika, że systematycznie zmniejsza się liczba dzieci i młodzieży w wieku przedszkolnym i szkolnym. W sposób radykalny rośnie udział ludności w wieku emerytalnym w ogóle ludności i będzie to trend długookresowy. ${ }^{5}$

\footnotetext{
${ }^{3}$ A. Baran., Edukacja w Polsce wobec zmian systemowych i demograficznych, „Polityka Społeczna” 5-6/2004.

${ }^{4}$ L. Cybulski, 1999, Edukacja a konkurencyjność regionów [w:] M. Klamut (red.), Konkurencyjność regionów, Wyd. AE we Wrocławiu, Wrocław.

${ }^{5}$ Strategia rozwoju edukacji 2007-2013, MEiN, Warszawa 2005.
} 
Zmiany demograficzne wywierają silną presję na rynek pracy i wymuszają zmiany w strukturze popytu i podaży usług edukacyjnych.

Oczekuje się, że zmiany w systemie oświaty doprowadzą do:

- upowszechnienia wykształcenia średniego;

- uwzględnienia w programach kształcenia treści dostosowanych do potrzeb rynku pracy;

- wprowadzenia do wszystkich szkół ponadpodstawowych zagadnień dotyczących życia gospodarczego i aktywnego zachowania się na rynku pracy;

- wprowadzenia do szkół problematyki orientacji zawodowej uczniów i poradnictwa zawodowego;

- uświadomienia roli i znaczenia kształcenia ustawicznego „uczenia się przez całe życie”.

W Polsce dokonał się znaczny postęp w poziomie wykształcenia ludności. Polacy traktują wykształcenie jak jedną z podstawowych dróg do zaspokojenia aspiracji i osiagnięcia wyższego statusu materialnego i społecznego. Wzrost motywacji do kontynuowania nauki wyraźnie widać w grupie osób młodych, zwłaszcza w wieku 25-34 lat. Generalnie, wyższy poziom wykształcenia w dużym stopniu przekłada się na wyższy wskaźnik zatrudnienia. Najbardziej zagrożone bezrobociem są osoby o niższym poziomie wykształcenia. Przeważająca część bezrobotnych ma więc wykształcenie podstawowe lub zasadnicze zawodowe. W 2003 r. stopa bezrobocia w grupie ludności z wykształceniem wyższym wynosiła 7,6\%, a wśród osób z wykształceniem zasadniczym zawodowym $24,0 \%{ }^{6}$ Te dane dowodzą, że wykształcenie może chronić przed wykluczeniem z rynku pracy. Oznacza to, że bardzo ważne są długofalowe działania zmierzające do poprawy poziomu wykształcenia społeczeństwa.

W 1999 r. rozpoczęto w Polsce wieloletnią, kompleksową reformę programów i metod pracy dydaktyczno-wychowawczej oraz struktury ustroju szkolnictwa. Reforma ma być drogą do podniesienia poziomu edukacji społeczeństwa przez upowszechnienie wykształcenia średniego i wyższego oraz wyrównywanie szans edukacyjnych.

\section{Kształcenie a aktywność zawodowa}

Istotne zmiany zachodzą w tzw. kształceniu ustawicznym. Warunkiem realizacji idei budowania społeczeństwa opartego na wiedzy jest nadanie w Polsce odpowiedniej rangi powszechnie rekomendowanej w ostatnich latach koncepcji uczenia się przez całe życie. Ta koncepcja (OECD - Paryż 1996) obejmuje rozwój indywidualny i rozwój cech społecznych we wszystkich formach i wszystkich kontekstach - w systemie formalnym i nieformalnym, tzn. w szkołach i placówkach kształcenia zawodowego, uczelniach i placówkach kształcenia dorosłych oraz w ramach kształcenia incydentalnego, czyli w domu, w pracy i w społeczności. Podkreśla się w niej potrzebę przygotowywania i zachęcania wszystkich dzieci do nauki przez całe życie, już od wczesnego wieku. Koncepcja ta ukierunkowuje działania w taki sposób, by zapewnić odpowiednie możliwości wszystkim - osobom dorosłym, pracującym i bezrobotnym, które muszą przekwalifikować się lub podnieść swoje kwalifikacje.

Powszechna idea budowania społeczeństwa opartego na wiedzy zmieniła stosunek do kształcenia, wywołując wzmożone zainteresowanie problematyką edukacyjna, a przede wszystkim kształceniem ustawicznym. Tendencja ta znajduje odzwierciedlenie zarówno w dokumentach międzynarodowych, jak i krajowych, które wytyczają priorytety i kierunki działań w tym zakresie. Z całą pewnością należy wymienić w tym miejscu Memorandum Komisji Wspólnot Europejskich dotyczace ksztatcenia ustawicznego z 30 października 2000 r., Deklarację Kopenhaska oraz przyjętą przez Radę Ministrów 8 lipca 2003 r. Strategię Rozwoju Kształcenia Ustawicznego do roku 2010.

${ }^{6}$ Strategia rozwoju edukacji 2007-2013, MEiN, Warszawa 2005. 
Ostatnio wyraźnie widać zmiany w kształceniu dorosłych. Liczba osób dokształcających się średnio rocznie w Polsce w ostatnich latach wynosi 1,2-1,5 mln osób, czyli około 9\% pracujących w gospodarce (w UE około 20\%). Wprawdzie odnotowuje się tendencję rosnącą, ale wiele należy jeszcze zmienić. W tym zakresie Polska musi dostosować się do Strategii Lizbońskiej, w której Unia Europejska zawarła priorytety dotyczące koncepcji „,uczenia się przez całe życie”. Komisja Europejska zobowiązała się wspierać współpracę w tej dziedzinie przez stworzenie spójnej strategii oraz podejmowanie wspólnych działań pozwalających na lepsze wykorzystanie środków w celu rozwoju kształcenia ustawicznego dostępnego dla wszystkich. ${ }^{7}$

Edukacja ustawiczna to zasada kształcenia organizująca nowy proces aktywnego poznania oraz stałego rozwoju intelektualnego i kulturalnego. Podstawową ideą kształcenia ustawicznego jest zachowanie ciagłości i systematyczności procesu uczenia się, co zapewnia stały rozwój i chroni przed zdezaktualizowaniem się zdobytej wiedzy. Kształcenie ustawiczne jest zgodne z potrzebami nowoczesnego społeczeństwa; uwzględnia przemiany czasu, wartości rynku oraz rytm indywidualnej egzystencji.

Współczesna idea uczenia się przez całe życie nawiązuje do wcześniejszych definicji kształcenia ustawicznego. Kształcenie ustawiczne to kompleks procesów oświatowych: formalnych, nieformalnych i incydentalnych, które niezależnie od treści, poziomu i metod umożliwiają uzupełnianie wykształcenia w formach szkolnych i pozaszkolnych, dzięki czemu osoby dorosłe rozwijają swoje zdolności, wzbogacają wiedzę, doskonalą kwalifikacje zawodowe lub zdobywają nowy zawód, zmieniają swoje postawy. Trzeba zaznaczyć, że w Polsce kształcenie ustawiczne jest utożsamiane z ideą uczenia się przez całe życie, która bezpośrednio jest łączona ze strategicznym celem przyjętym przez Radę Europejską (Lizbona 2000). Porównując definicję „kształcenia ustawicznego" przyjętą w Polsce z definicją ,kształcenia przez całe życie” przyjętą w Unii Europejskiej można stwierdzić, że idea kształcenia przez całe życie znaczy coś więcej. Według definicji podanej w Rezolucji Rady Unii Europejskiej z 27 czerwca 2002 r. „(...) pojęcie lifelong learning (uczenie się przez całe życie) powinno dotyczyć uczenia się od fazy przedszkolnej do późnej emerytalnej, włączając w to całe spektrum uczenia się formalnego (w szkołach i innych placówkach systemu edukacji), pozaformalnego (w instytucjach poza systemem edukacji) i nieformalnego (naturalnego). Ponadto, powinno się ono odnosić do wszelkiej, trwającej przez całe życie, aktywności uczenia się, mającej na celu rozwój wiedzy, kompetencji i umiejętności w perspektywie osobistej, obywatelskiej, społecznej oraz zorientowanej na zatrudnienie. Zasadniczym odniesieniem w tym względzie powinna być osoba jako podmiot uczenia się, co podkreślać ma znaczenie prawdziwej równości szans i jakości w procesie uczenia się”. W polskich realiach, mówiąc o „,...) kształceniu ustawicznym - należy przez to rozumieć kształcenie w szkołach dla dorosłych, a także uzyskiwanie, uzupełnianie wiedzy ogólnej, umiejętności i kwalifikacji zawodowych w formach pozaszkolnych (formy uzyskiwania i uzupełniania wiedzy ogólnej, umiejętności i kwalifikacji zawodowych w placówkach i ośrodkach będących jednostkami organizacyjnymi systemu oświaty) przez osoby, które spełniły obowiązek szkolny" (Ustawa o systemie oświaty, art. 3 pkt 17). Położenie akcentu na integrację wyróżnionych form kształcenia sprawia, że proces kształcenia ustawicznego zyskuje nowy, całościowy charakter.

Komplementarne traktowanie kształcenia formalnego, nieformalnego i incydentalnego - przy uwzględnieniu standardów kwalifikacji zawodowych - umożliwia przenikanie się struktur organizacyjnych systemu edukacji, ułatwia zdobywanie i uznawanie kwalifikacji zawodowych. Jest

\footnotetext{
${ }^{7}$ M. Budzyńska, 2004, Koncepcja ksztatcenia ustawicznego w Unii Europejskiej jako jeden ze sposobów realizacji Strategii Lizbońskiej, Urząd Komitetu Integracji Europejskiej, Warszawa (publikacja w wersji elektronicznej).
} 
to również płaszczyzna do szerokiej wymiany doświadczeń natury merytorycznej, metodycznej i organizacyjnej. To także krok w kierunku budowania otwartego i elastycznego systemu edukacji, rzeczywistego wspierania aktywności poznawczej i przedsiębiorczości, prowadzących do zwiększania szans zatrudnienia na współczesnym rynku pracy. Dynamizm przemian zmusza współczesnego człowieka do realizowania w praktyce idei uczenia się przez całe życie. Edukacja ustawiczna staje się jednym z najlepszych sposobów sprostania wyzwaniom wynikającym z gwałtownego rozwoju technologicznego, globalizacji czy przeobrażeń społecznych i ekonomicznych. Warunki nowej rzeczywistości wymuszają na jednostce konieczność nieustannego podnoszenia kwalifikacji i ciagłego poszerzania wiedzy wraz z eksplorowaniem zastanego otoczenia, w celu przystosowania się do zmieniającego się w szybkim tempie świata. Ciagła konieczność aktualizacji zdobytej wiedzy staje się jednym z najważniejszych wyzwań cywilizacyjnych, jakie stawia przed człowiekiem społeczeństwo oparte na wiedzy. W kontekście tych wyzwań współczesności edukację XXI w. należy postrzegać jako proces, który trwa całe życie.

\section{Literatura}

1. Baran A., Edukacja w Polsce wobec zmian systemowych i demograficznych, „Polityka Społeczna” 5-6/2004

2. Budzyńska M., 2004, Koncepcja kształcenia ustawicznego w Unii Europejskiej jako jeden ze sposobów realizacji Strategii Lizbońskiej, Urząd Komitetu Integracji Europejskiej, Warszawa (publikacja w wersji elektronicznej, scholaris.pl)

3. Cybulski L., 1999, Edukacja a konkurencyjność regionów [w:] M. Klamut (red.), Konkurencyjność regionów, Wyd. AE we Wrocławiu, Wrocław

4. Fiodor B., 2001, Polityka państwa a powiększanie zasobów kapitału ludzkiego w Polsce w latach dziewięćdziesiatych [w] J. Jagas (red.), Produktywność i wydajność w okresie transformacji gospodarki polskiej, Wydawnictwo Uniwersytetu Opolskiego, Opole

5. Słownik języka polskiego, Wydawnictwo Naukowe PWN, Warszawa 1998

6. Strategia rozwoju edukacji 2007-2013, MEiN, Warszawa 2005

\section{Is a Lifelong Learning an Entrepreneurial Attitude?}

The main thesis of the article is connected with the constant attempts to the implementation a new educational system in Poland. Some new opportunities have occurred since Poland entered the European Union as we can now make use of other countries' experience in the reforming area. Nowadays we are dealing with a new term in Poland i.e. lifelong learning. According to the author such a view on the education has its roots in constant changes in Polish society and economy. Open trade economy has influenced Polish scholar system - the trainees/ /students are focused on being successful on the market, especially on the job market. Traditional educational system in Poland was enriched by elements of entrepreneurship. The author describes Polish education as an investment, which is a condition of economic, scientific and social development. Constant or lifelong learning is therefore described as a social and economic phenomenon. 